\title{
Human Resource Planning and Audit - a Case Study of HEG Limited
}

\author{
Rajesh K. Yadav ${ }^{1, *}$, Nishant Dabhade ${ }^{2, * *}$ \\ ${ }^{1}$ Associate Professor \& Head, Department of Management, RKDF College of Engineering, \\ Bhopal (M.P.), India \\ ${ }^{2}$ Department of Management, RKDF College of Engineering, Bhopal (M.P.), India \\ ${ }^{*, \star * E-m a i l ~ a d d r e s s: ~ d r r a j e s h k y a d a v @ y a h o o . c o m ~, ~ n i s h a n t . d a b h a d e . m g m t @ g m a i l . c o m ~}$
}

\begin{abstract}
Prompt advancement in product / service and process technology, many operations in the manufacturing and service industries in recent years require competitive HR practices. So this research study stresses on HR planning and audit practices. HR planning is all about good management; good strategic management; good business management and particularly good people management. It is important that you put thought and careful planning into your human resource practices. And the purpose of the HR Audit is to conduct a more in-depth analysis of the HR function to identify areas of strength and weakness and where improvements may be needed. Conducting an audit involves a review of current practices, policies, and procedures, and may include benchmarking against organizations of similar size and/or industry. This research aims to figure out the practices, employee perception and measures adopted by HEG limited for Human resource planning and audit. Chi square test is applied at (.05 or $5 \%$ ) significance level in this paper to check the authenticity of data given by the respondents. Findings suggests that it is difficult to assess accurate HR planning and adopting accurate audit practices because practices itself does not produce right or wrong answers, but it produces a series of alternatives from which the right course of action can be chosen.
\end{abstract}

Keywords: Workforce; Measures; Technology; career progression; Policy implementation etc.

\section{INTRODUCTION}

The historical role of Human Resources has changed spectacularly since its inception in the early 1900s. Formerly it was mainly a clerical function but now human resource is a strategic partner in planning and attaining organizational policies and goals. Today's business climate puts the obligation on the HR department to accept the challenge of doing more with less, while contributing value toward business objectives. Human resources also has to address the rapidly changing conditions affecting the type of employees required and their changing needs, so the function requires flexible and knowledgeable practitioners. Hence HR planning has become an integral part of business. All companies, organizations, institutions consist of people and are meant to serve the people with products and services. Humans, therefore, are not only the resources of organizations but are the main instrument of their 
progress. It is not enough to say ,people are our most precious asset of business. Instead we must say our company or organization (including its results) is a creation of our people.

In order to pace the talk of being a "business partner," HR managers have to provide real evidence that they are having a strategic business impact. Management is often asking, "How are we doing?" However, this is not always an easy question to answer. This is especially so, when it is difficult to obtain some type of objective measuring tool to determine how well a certain HR function is performing. To validate the claim of being "business partners", HR managers must clearly demonstrate how HR services can accomplish the business objectives set forth by the organization. The HR function is often overlooked for audits/measurement tools, to assess its effectiveness and legal regulatory compliance. However, the HR Audit is a process that sets the stage for a true transformation in HR strategy and services. It links HR systems and services to organizational objectives while focusing on the business needs of internal customers.

The success of a business is directly linked to the performance of those who work for that business. Underachievement can be a result of workplace failures. Because hiring the wrong people or failing to anticipate fluctuations in hiring needs can be costly, it is important that you put effort into human resource planning. Planning for HR needs will help to ensure your employees have the skills and competencies your business needs to succeed. It will better prepare you for staff turnover, recruitment, and strategic hiring - and improve stress when you have emergency/last-minute hiring needs. With effective human resource planning, HR audit implies critical examination and evaluation of policies, programs and procedures in human resource management. [4,5]

\section{DOES HR PLANNING AND AUDIT MATTERS?}

In essence, workforce or HR planning is about predicting future labor market needs. It requires an understanding of the make-up of the current workforce, an investigation into future service needs and an analysis of the type and size of workforce required to meet them. It is becoming increasingly important for agencies as they adopt new ways of operating in order to adapt to changes.

The challenge will be to ensure that agencies can minimize the costs and grab the opportunities that such changes brings - quicker career progression, effective recruitment, and more flexible job design and workforce deployment. By identifying workforce capabilities and by considering what will be needed in the future and planning systematically, managers can limit the risks associated with unanticipated events. In particular, HR planning will help organizations to:

- Identify potential problems, manage risk and minimize crisis management cycles.

- Contain human resources costs, including the cost of turnover, absenteeism, structural changes and staff movements.

- Develop workforce skills that take time to grow.

- Optimize the use of human, financial and other resources. [4] 


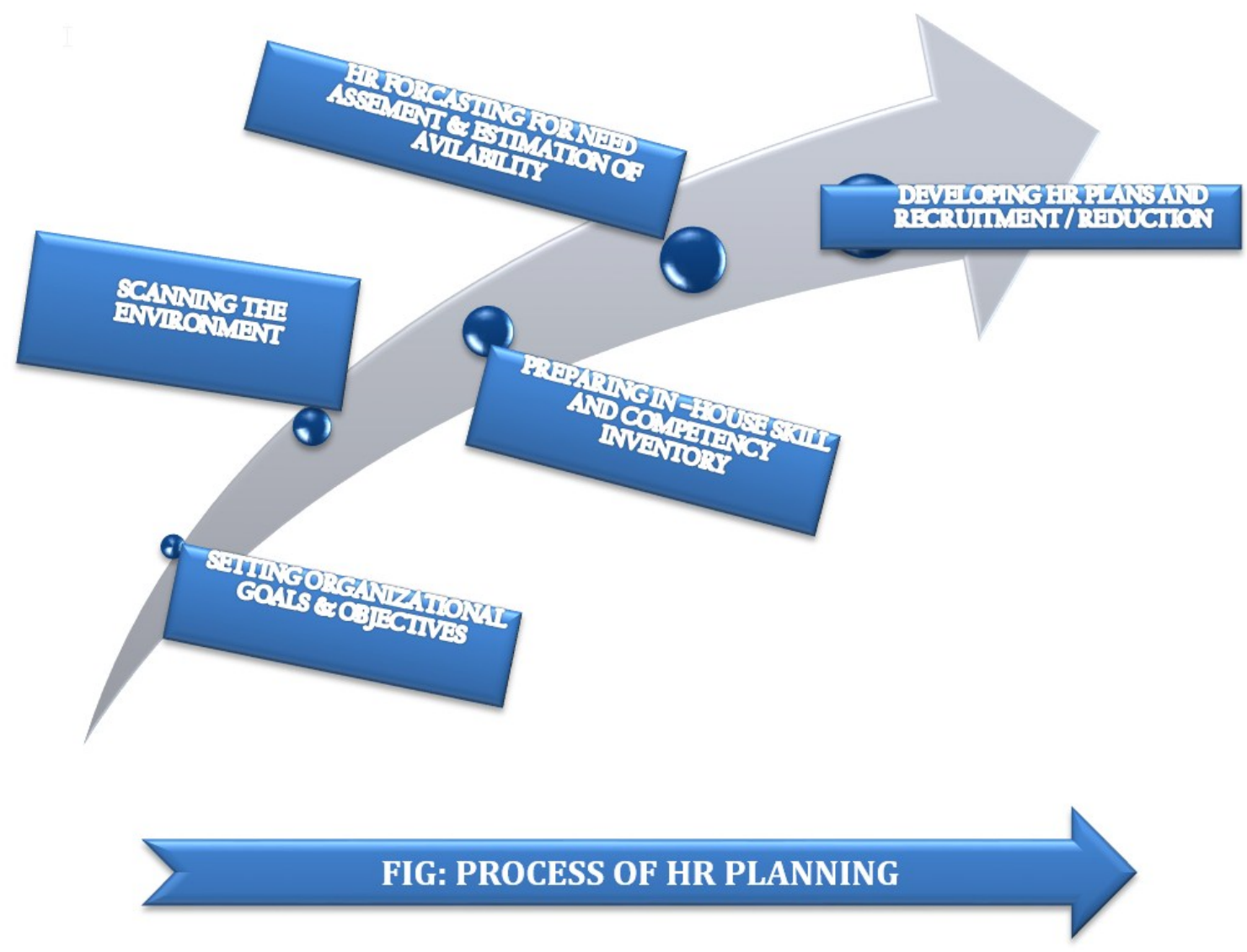

Fig. 1. Process of HR planning.

(Source: Pravin Durai (2010), Human resource Management, Pearson Education Publications) [9].

Apart from it the reason for conducting an HR audit is to find out how effective and efficient the organization's HR activities are and to determine the areas for improvement and identify changes. The purpose of the HR Audit is to conduct a more in depth analysis of the HR function to identify areas of strength and weakness and where improvements may be needed. Conducting an audit involves a review of current practices, policies, and procedures, and may include benchmarking against organizations of similar size and/or industry. An HR Audit in effect includes five different components.

\section{Functional Audit}

This aspect of the HR audit examines:

- Your HRD systems and procedures, encompassing training and development, organization development and career development.

- Whether your HRD systems and procedures are aligned with the HRM systems and procedures to promote competence, confidence and performance. This includes job design, HR planning, performance management systems, selection and staffing.

- Fairness and consistency in compensation and benefits, employee relations and your HR record keeping, particularly in regard to providing timely management information. 


\section{Service Audit}

This aspect of the audit activity looks at the service responsiveness and reliability of the HR function. This will include an assessment of such things as response times, willingness to help line managers/staff, and the knowledge of the HR staff etc.

\section{Compliance Audit}

This assesses the degree to which HR is compliant with the relevant legislation - e.g. Labor Laws, etc. This part of the audit will assess whether the required policies, practices, and procedures exist, and to what extent management and labor have been trained to enact these codes of best practice.

\section{Financial Management Audit}

A comprehensive audit of HR systems and procedures needs to go beyond the inspection level. Basic financial ratios/scorecard measures appropriate for a staff function like HR need to be put in place to audit the efficiency of the various HR functions.

\section{Strategic Audit}

Each organization should have an overall people management strategy that aims to increase the value of employees to the business. The strategic audit will examine whether the HR strategy, policies and processes are aligned with and support the achievement of the business's mission and objectives.

\section{OVERVIEW OF HEG LIMITED}

HEG Limited was established in technical and financial collaboration with Societe Des Electrodes Et Refractaires Savoie (SERS), a subsidiary of Pachiney of France in the year 1977. HEG is the leading manufacturer and exporter of Graphite Electrodes in India. HEG is the world's largest single site plant of Graphite Electrodes with a production capacity of 80,000 MT per annum. It is an ISO 9001 \& ISO 14000 Certified Company. HEG also operates three power generation facilities with a total rated capacity of about 77 MW. HEG Ltd, a premier company of the LNJ Bhilwara group. It has one of the largest integrated Graphite Electrode plants in the world, processing sophisticated UHP (Ultra High Power) Electrodes.

The company exports over $80 \%$ of its production to more than 25 countries of the world. The position the company enjoys today in India and abroad is largely due to its commitment to constant up gradation of its product quality to match international standards and to meet new challenges to win and excel in all situations. In the 1990's, we set our "Vision" to be: "A vibrant globally acknowledged top league player in Graphite Electrodes and allied businesses with commitment to growth, innovation, quality and customer focus". In Graphite, our focus is on UHP grade electrodes, and we have expanded our product range and established the same on some of the toughest furnaces of our customers.

Today, we have years of experience supplying quality UHP grade electrodes all over the world. To maintain our competitiveness, we have set up a Captive Power Plant totaling more than $77 \mathrm{MW}$. As a responsible graphite electrode manufacturer, we continue to invest in technology, development of new products and in our human resources. [1] 


\section{ASSURANCES AT HEG LIMITED}

\section{Human Resource Management}

HEG operates in an industry where technical competence and expertise is paramount. The company maintains that Human Resources are a key driver of business growth.

\section{Organizational Development}

HEG believes that productivity enhancement comes from well-structured and focused training and development programs. The Company continually endeavors to equip its workforce with the latest tools and techniques to help them raise their level of efficiency and effectiveness. In 2003, M/S Hewitt Associates were retained by HEG for HR Intervention and initiatives broadly covering Job Evaluation, Performance Measurement, Competency Assessment and Development, Organization Re-structuring and Reward Management. The company has subsequently implemented most of the recommendations and is of the view that each of these initiatives would go a long way in fostering an environment that allows employees to fully utilize their abilities to perform better and to drive the performance of the company.

\section{Fostering a Quality-conscious organizational culture}

Quality is not merely limited to being the cornerstone of HEG's sustainable competitive advantage but is actively sought to be used as a facilitator of business growth. The Company on its part, constantly engages its employees, programs aimed at ingraining a culture of quality in its workforce. HEG has further extended the quality initiative to its processes via a comprehensive Statistical Process Control System (SPC) based on Six Sigma Tools \& Techniques. This has enabled the Company to attain international standards in manufacturing besides enhancing productivity. Moreover, the Company invites global consultants from time to time to seek assistance in its efforts to continuously improve processes.

\section{Performance Metrics and Remuneration}

The Company manages a highly-motivated and capable team of employees. Besides, the nature of the business requires that in-house competence and expertise be conserved and developed. As a manifestation of that concept, HEG has outlined a performance management system with the Balanced Score Card as the core. This seeks to not only motivate employees but also attract fresh talent into the fold.

\section{Competency Sustainment}

Present-day best practices require that succession planning not be restricted to senior management but also encompass key positions across relevant job categories. HEG as a truly global and modern organization believes in preparing tomorrow's leaders today. To that end, the Company has put in place an effective process to sustain a talent pool that can seamlessly handle organizational change at all times.

\section{Industrial Relations}

HEG has consistently chosen to engage its unions and labor force while initiating major changes that directly affect them. Furthermore, employees are empowered to bring to the fore issues relevant to them from time to time. The manner of engagement between the management and its workforce over the years has led to the creation of mutual understanding and trust between the two. [1] 


\section{CONTENTS OF HR AUDIT PRACTICES}

In conducting human resources audit, an employment policy or practice includes contents shown in following Figure no. 2, but it is not limited to these contents only. It may vary organization to organization.

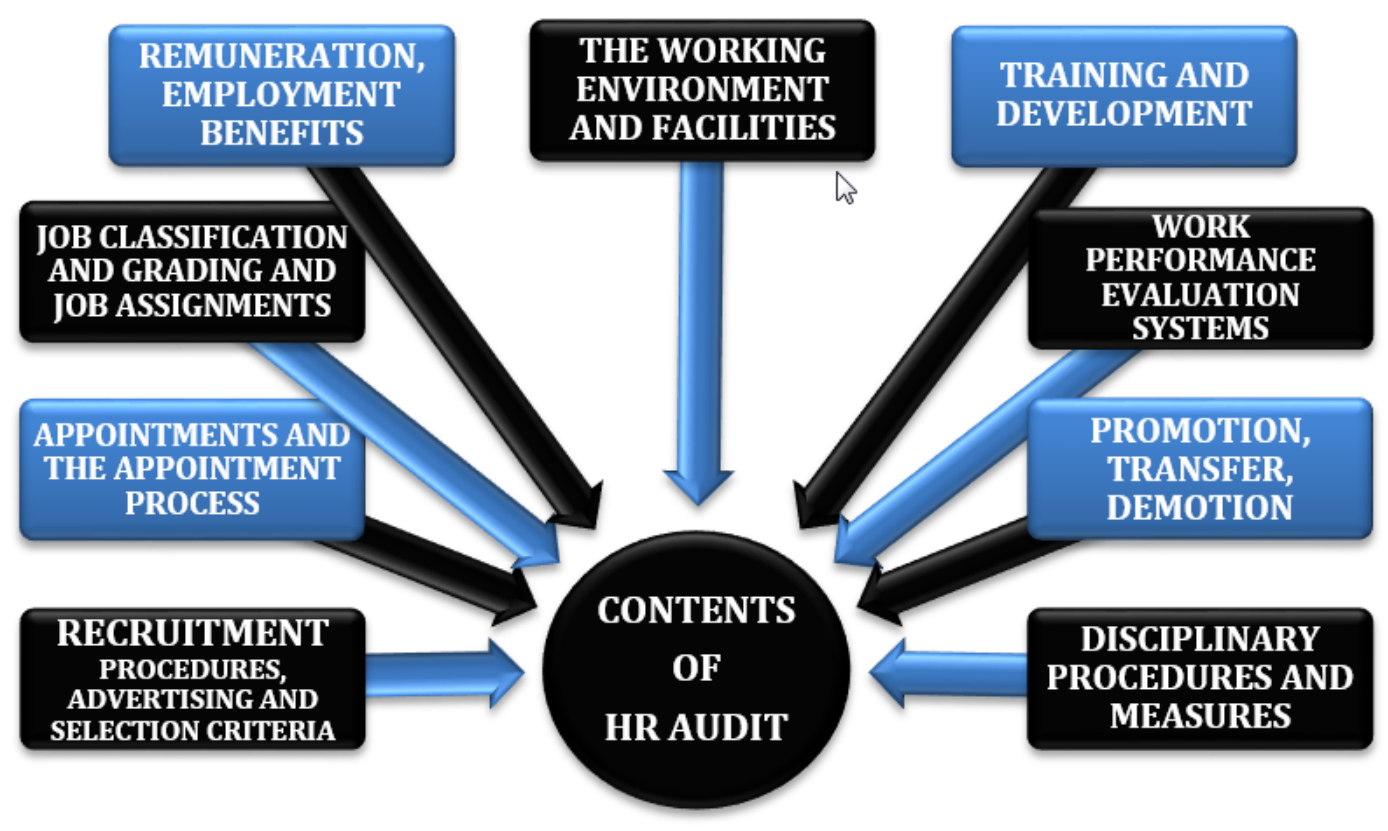

Fig 2. Contents of employment policy for HR audit.

\section{RATIONAL OF THE STUDY}

Manpower or Human resources are asset for any organization and specifically for the manufacturing units, where employees act as the talent warehouse.

Due to the importance of human resources, human resource planning is also in the limelight. To utilize the employee's efficiency it is imperative to have full description about the employee as well as the job for which he is available.

Workforce planning will be critical to the HEG limited, as it administers the generational change taking place in the workforce. Labor market supply and demand factors, work and family considerations, and equity and diversity issues are rapidly taking place.

For example, The Company has an older age profile and its workforce is mature aged and significant numbers of senior staff are approaching retirement, which means valuable corporate knowledge could be lost.

Hence, in this dynamic scenario, the importance of human resource planning and audit can't be neglected. On the other hand Auditing HR practices require assessing the arrangement of services offered by an HR department. Hence effective implementation of HR policies secures utmost importance for which HR audit is conducted.

This research work focuses on practices, employee perception and measures adopted by HEG for Human resource planning and audit. 


\section{REVIEW OF LITERATURE}

Sanjeev K. Bordoloi, Hirofumi Matsuo (2001) studies that because of rapid evolution in product and process technology, many operations in the manufacturing and service industries in recent years require workers to acquire and maintain more extensive "knowledge stock" than before. In this paper, we address the human resource planning in these knowledgeintensive operations. We focus on the management of knowledge mix, that is, the mix of workers in different knowledge levels. This research was conducted in a semiconductor equipment manufacturing plant that uses an assembly line to achieve high productivity. However, the plant also needs to increase ability to deal with a high degree of product customization, frequent technology and product changes, and relatively low volume of production, which collectively require a high level of knowledge development for each worker. We extend methodology developed for managing production and work-in-process inventory levels for a manufacturing system that is subject to random production yields. However, the structure of our problem is different, and thus requires a separate mathematical development. Our results indicate that the company we studied underestimated the ideal number of workers in the higher knowledge levels in the steady state. But this problem, by itself, can be taken care of by a good intuitive heuristic. We then demonstrate that our control rule is superior to the good intuitive rule from the point of view of additional stability that is obtained from less variability in the work force levels. We offer managerial implications of this additional stability using our computational results [10].

Ghazala Ishrat, Javed Habib (2012) finds that in the changing economic and business environment, proper Human Resource Management has assumed a crucial role in the growth of the organization. It has become imperative to re-look at this most important asset of the organization. The main objective behind this research was to gain in-depth knowledge of the Human Resource and the effectiveness of HR functions within an organization. The HR audit in University was planned to get a clear judgment about the overall status of most faculties/Departments and to find out whether existing systems and procedures are yielding desired result. This information will be an invaluable input while making strategic decisions. The human resource audit involved examining current policies, practices and strategies of all the departments/faculties to verify the effectiveness and helping University to improve its productivity, transparency and efficiency. To conduct Human Resource Audit in University extensive study on various aspects related to faculties, students and staff were analyzed and studied through interviews of staff at various levels, observation of working of non teaching staff, taking responses from students and staff by questionnaire method and documents review at various levels. The firsthand experience has helped us in our specialization in HR as this enhanced our prospective of thoughts. The concise suggestions/ recommendations emerged after in depth analysis and study will provide with a wide scope to understand the functions and mechanism of working in any organization [4].

Dr. Shikha N. Khera, Ms. Karishma Gulati (2012) states that Human resource information system (HRIS) is not new concept but it is recuperating day by day with changing environment. Its major role is in human resource planning (HRP) which itself a crucial activity in any organization. Ineffective HRP can lead to extra or fewer numbers of employees than needed. Both over and under number of employees can create crappy situations. HRIS helps in proper planning of human resources. This paper focuses on the role of HRIS in HRP. The research is empirical in nature as 127 respondents from top 7 IT companies (as per their market share) are taken to see the sights of the objectives. The survey is done with the 
assistance of the questionnaire. After investigation it is concluded that HRIS has various benefits but the foremost is HRIS stores ample data about the employees of the organizations that helps in escalating the snail's pace of HRP. HRIS also helps in the strategic activities of HR managers and more in training and development, succession planning, applicant tracking in recruitment and selection and manpower planning. While analyzing the overall contribution of HRIS in HRP it is concluded that HRIS identifies occupied and unoccupied positions in an organization very effectively and accurately [3].

The paper of Linda O'Brien-Pallas, Stephen Birch, Andrea Baumann, Gail Tomblin Murphy (2001) is one in 10 in a series of papers commissioned by the World Health Organization to take stock of the state of the science of human resources for health activities in the year 2000. This paper provides an analysis of how labor market indicators can be integrated into service planning, discusses whether planning is sufficiently responsive and flexible to retain relevance and validity in rapidly changing health systems, describes different models and approaches to linking and integrating workforce planning and service planning, discusses methodological approaches to integrating planning, and examines effective approaches to the use of computer based scenario modeling to support assessment of current and future planning options. The context and broad cross-cutting themes of public sector, political, social, and macro-economic changes have been considered. Where publications exist, empirical evidence serves as the basis for this analysis and country examples have been highlighted. While strides have been made in the practice of resource planning world-wide, health human resource planning in most countries has been poorly conceptualized, intermittent, varying in quality, profession specific in nature, and without adequate vision or data upon which to base sound decisions [7].

Dave Ulrich (1997) studies that many talk about measuring human resources (HR), but get lost because the issues are confusing. What to measure? How to measure it? When to measure? Where to measure? These questions make measurement of HR difficult. This article reviews the history of HR measurement; summarizes how HR measures may be done for professionals, practices, and functions; and offers specific guidelines for improving HR measures [2].

Mark S. Van Clieaf (1992) studies that new approaches to executive search and executive resource planning are required if these functions are to have a strategic impact on improving organizational performance. The need to map and match specific executive perspectives and competencies to the future needs of the business is required if executive search and executive resource planning are to become strategic management tools. This paper examines the three "drivers" of strategic leadersbip and provides a framework for synchronizing specific executive perspectives and competencies to these three drivers. A case study illustrates bow common practices such as raiding direct competitors for executive talent or always promoting from within may be counterproductive to the strategic needs of the business. Recommendations for applying these new concepts at the board corporate, and strategic business unit level are made [8].

\section{RESEARCH METHODOLOGY}

The research study is a descriptive study. Questionnaire is designed to collect the data from various employees and a few officials from HR department of HEG limited located at Bhopal (M.P.) [6]. 


\section{1. Objectives of the study}

- To analyze the practices used by HEG for HR Planning and Audit.

- To study the employees perception about the HR Planning and audit at HEG.

- To identify the measures adopted by HEG for HR planning and Audit.

\section{2. Hypothesis}

- The HR Planning and audit practices have positive effect on demand and supply of employees at HEG.

- Employees have negative perception about the HR Planning and Audit at HEG.

- Measures adopted for HR Planning and Audit by HEG fulfill organization's need for human Resource.

\section{3. Sampling plan}

- Sample Unit: Employees and a few officials from HR department of HEG limited located at Bhopal (M.P.).

- Sample Size: 110 employees (100 employees and 10 HR officials)

\section{4. Research approach}

Survey (Primary data is collected through self structured questionnaire).

\section{QUESTIONNAIRE}

\section{1. Questionnaire for HR officials}

9. 1. 1. HEG properly works out on HR Planning to achieve targets?

\begin{tabular}{|c|c|c|c|}
\hline S.NO. & OPINION & NO. & PERCENT (\%) \\
\hline 1 & Strongly agree & 3 & 30 \\
\hline 2 & Agree & 5 & 50 \\
\hline 3 & Disagree & 2 & 00 \\
\hline 4 & Strongly disagree & 0 & 100 \\
\hline Total & \multicolumn{2}{|c|}{10} & $\chi^{2}(.05)=7.81$ \\
\hline
\end{tabular}

When it is asked to the HEG officials that HEG properly works out on HR Planning, then majority of $30 \%$ and $50 \%$ users were strongly agree and agree respectively while only $20 \%$ were disagree and none is strongly disagree. The chi square value radically shows that opinion of the respondents was significantly identical on asking HR Planning.

9. 1. 2. HEG is doing appropriate planning \& Audit for HR requirements?

\begin{tabular}{|c|c|c|c|}
\hline S.NO. & OPINION & NO. & PERCENT (\%) \\
\hline 1 & Strongly agree & 3 & 30 \\
\hline 2 & Agree & 4 & 40 \\
\hline
\end{tabular}




\begin{tabular}{|c|c|c|c|}
\hline 3 & Disagree & 2 & 20 \\
\hline 4 & Strongly disagree & 1 & 10 \\
\hline Total & & 10 & 100 \\
\hline
\end{tabular}

$$
\chi^{2}=2 \quad \mathrm{df}=3, \quad \chi^{2}(.05)=7.81
$$

On asking to the officials of HEG that planning \& Audit is appropriate in HEG for HR requirements, then group of $30 \%$ and $40 \%$ were strongly agree and agree respectively and only $20 \%$ and $10 \%$ were disagree and strongly disagree in that order. The chi square value entirely shows that the opinion of respondent was significantly similar and majority of employees is in favor that HEG opt appropriate practices.

9. 1. 3. HR provides an adequate pool of employees after HR Planning in HEG?.

\begin{tabular}{|c|c|c|c|}
\hline S.NO. & OPINION & NO. & PERCENT (\%) \\
\hline 1 & Strongly agree & 4 & 40 \\
\hline 2 & Agree & 2 & 20 \\
\hline 3 & Disagree & 3 & 30 \\
\hline 4 & Strongly disagree & 1 & 10 \\
\hline Total & & 10 & 100 \\
\hline \multicolumn{2}{|c|}{$\chi^{2}=2 \quad \mathrm{df}=3, \quad \chi^{2}(.05)=7.81$} \\
\hline
\end{tabular}

When it is asked to the officials that HR provides an adequate pool of employees after HR Planning, then $40 \%$ were strongly agree and $20 \%$ were agree and $30 \%$ and $10 \%$ were disagree and strongly disagree respectively. The chi square value completely shows that the opinion of respondents was significantly identical.

9. 1. 4. HR Planning in HEG is according to the skills, knowledge and education of existing employees?

\begin{tabular}{|c|c|c|c|}
\hline S.NO. & OPINION & NO. & PERCENT (\%) \\
\hline 1 & Strongly agree & 6 & 60 \\
\hline 2 & Agree & 1 & 10 \\
\hline 3 & Disagree & 3 & 30 \\
\hline 4 & Strongly disagree & 0 & 00 \\
\hline Total & & 10 & 100 \\
\hline
\end{tabular}

$$
\chi^{2}=8.4 \mathrm{df}=3, \quad \chi^{2}(.05)=7.81
$$

When it is asked to the HEG officials that planning is done according to the skills, knowledge and education, then majority of $60 \%$ and $10 \%$ users were strongly agree and agree respectively while only $30 \%$ were disagree and none is strongly disagree respectively. The chi square value radically shows that opinion of the respondents was significantly different. 
9. 1. 5. HEG has career planning, Training and appraisal system to identify individual skills, interests and needs, and which contributes in productivity and/or developmental assistance?

\begin{tabular}{|c|c|c|c|}
\hline S.NO. & OPINION & NO. & PERCENT (\%) \\
\hline 1 & Strongly agree & 3 & 30 \\
\hline 2 & Agree & 5 & 50 \\
\hline 3 & Disagree & 1 & 10 \\
\hline 4 & Strongly disagree & 1 & 10 \\
\hline Total & & 10 & 100 \\
\hline
\end{tabular}

$\chi^{2}=4.4 \quad \mathrm{df}=3, \quad \chi^{2}(.05)=7.81$

On asking to the officials of HEG that HEG properly identifies individual needs, then group of $30 \%$ and $50 \%$ were strongly agree and agree respectively and only $10 \%$ and $10 \%$ were disagree and strongly disagree in that order. The chi square value entirely shows that the opinion of respondent was significantly same.

9. 1. 6. HEG has formal HR Filing system?

\begin{tabular}{|c|c|c|c|}
\hline S.NO. & OPINION & NO. & PERCENT (\%) \\
\hline 1 & Strongly agree & 4 & 40 \\
\hline 2 & Agree & 5 & 50 \\
\hline 3 & Disagree & 0 & 00 \\
\hline 4 & Strongly disagree & 1 & 10 \\
\hline Total & & 10 & 100 \\
\hline
\end{tabular}

$$
\chi^{2}=6.8 \quad \mathrm{df}=3, \quad \chi^{2}(.05)=7.81
$$

When it is asked to the officials that HEG has formal HR Filing system, then $40 \%$ were strongly agree and $50 \%$ were agree and none is disagree and only $10 \%$ were strongly disagree respectively. The chi square value completely shows that the opinion of respondents was significantly identical when it comes to HR filing system.

9. 1. 7. HR audit give a sense of confidence in the human resource department that it is well managed and prepared to meet potential challenges and opportunities?

\begin{tabular}{|c|c|c|c|}
\hline S.NO. & OPINION & NO. & PERCENT (\%) \\
\hline 1 & Strongly agree & 3 & 30 \\
\hline 2 & Agree & 4 & 40 \\
\hline 3 & Disagree & 2 & 20 \\
\hline 4 & Strongly disagree & 1 & 10 \\
\hline Total & & 10 & 100 \\
\hline
\end{tabular}

$$
\chi^{2}=2 \quad \mathrm{df}=3, \quad \chi^{2}(.05)=7.81
$$


When it is asked to the officials that HR audit give a sense of confidence to meet potential challenges and opportunities, then $30 \%$ were strongly agree and $40 \%$ were agree and said that they are satisfied and $20 \%$ and $10 \%$ were disagree and strongly disagree respectively. The chi square value completely shows that the opinion of respondents was significantly similar when it comes to meet potential challenges and opportunities by HR audit.

9. 1. 8. Contract staff is considered in HR audit process with permanent employees by HEG?

\begin{tabular}{|c|c|c|c|}
\hline S.NO. & OPINION & NO. & PERCENT (\%) \\
\hline 1 & Strongly agree & 2 & 20 \\
\hline 2 & Agree & 3 & 30 \\
\hline 3 & Disagree & 3 & 30 \\
\hline 4 & Strongly disagree & 2 & 100 \\
\hline Total & & 10 & 20 \\
\hline \multicolumn{4}{c}{$\mathrm{df}=3, \quad \chi 2(.05)=7.81$} \\
\end{tabular}

When it is asked to the HEG officials that Contract staff is considered in HR audit process with permanent employees, then majority of $20 \%$ and $30 \%$ users were strongly agree and agree respectively while only $30 \%$ and $20 \%$ were disagree and strongly disagree respectively. The chi square value radically shows that opinion of the respondents was significantly similar.

9. 1. 9. HEG maintains the records of Leave, skills, employee performance, training \& experience of the employee?

\begin{tabular}{|c|c|c|c|}
\hline S.NO. & OPINION & NO. & PERCENT (\%) \\
\hline 1 & Strongly agree & 4 & 40 \\
\hline 2 & Agree & 5 & 50 \\
\hline 3 & Disagree & 1 & 00 \\
\hline 4 & Strongly disagree & 0 & 100 \\
\hline Total & & 10 & 0 \\
\hline
\end{tabular}

$$
\chi^{2}=6.8 \quad \mathrm{df}=3, \quad \chi^{2}(.05)=7.81
$$

When it is asked to the officials that HEG maintains the records of necessaries, then $40 \%$ were strongly agree and $50 \%$ were agree and said that they are satisfied and $10 \%$ were disagree and none is strongly disagree respectively. The chi square value completely shows that the opinion of respondents was significantly identical. 
9. 1. 10. HEG considers Leaves and Overtime of the employees in HR audit Process?

\begin{tabular}{|c|c|c|c|}
\hline S.NO. & OPINION & NO. & PERCENT (\%) \\
\hline 1 & Strongly agree & 4 & 40 \\
\hline 2 & Agree & 6 & 60 \\
\hline 3 & Disagree & 0 & 00 \\
\hline 4 & Strongly disagree & 0 & 00 \\
\hline Total & & 10 & 100 \\
\hline
\end{tabular}

$$
\chi^{2}=10.8 \quad \mathrm{df}=3, \quad \chi^{2}(.05)=7.81
$$

When it is asked to the officials that they considers Leaves and Overtime of the employees in HR audit Process, then $40 \%$ were strongly agree and $60 \%$ were agree and none is disagree and strongly disagree respectively. The chi square value completely shows that the opinion of respondents was significantly different.

9. 1. 11. Job analysis accurately identifies the key objectives and responsibilities of the position?

\begin{tabular}{|c|c|c|c|}
\hline S.NO. & OPINION & NO. & PERCENT (\%) \\
\hline 1 & Strongly agree & 3 & 30 \\
\hline 2 & Agree & 4 & 40 \\
\hline 3 & Disagree & 2 & 20 \\
\hline 4 & Strongly disagree & 1 & 10 \\
\hline Total & & 10 & 100 \\
\hline
\end{tabular}

$$
\chi^{2}=2 \quad \mathrm{df}=3, \quad \chi^{2}(.05)=7.81
$$

On asking to the officials that Job analysis accurately identifies responsibilities of the position then mass of $30 \%$ were strongly agree and as a group of $40 \%$ were agree and $20 \%$ respondents were disagree and only $10 \%$ were strongly disagree about it. The chi square value clearly indicates that the opinion of respondents was significantly similar.

9. 1. 12. HR Climate, Job Satisfaction, working conditions, employee salaries and motivational level of employees are considered in HR audit process by HEG.

\begin{tabular}{|c|c|c|c|}
\hline S.NO. & OPINION & NO. & PERCENT (\%) \\
\hline 1 & Strongly agree & 2 & 20 \\
\hline 2 & Agree & 6 & 60 \\
\hline 3 & Disagree & 1 & 10 \\
\hline 4 & Strongly disagree & 1 & 10 \\
\hline Total & & 10 & 100 \\
\hline
\end{tabular}

$$
\chi^{2}=6.8 \quad \mathrm{df}=3, \quad \chi^{2}(.05)=7.81
$$

On asking to the officials of HEG that climate, Salary, satisfaction, working conditions are considered in HR audit process then only $20 \%$ were strongly agree and as a group of $60 \%$ 
were agree and $10 \%$ respondents were disagree and again $10 \%$ were strongly disagree about it. The chi square value clearly indicates that the opinion of respondents was significantly similar.

\section{2. Questionnaire for employees}

9. 2. 1. Are the HR practices consistent with the organization's mission?

\begin{tabular}{|c|c|c|c|}
\hline S.NO. & OPINION & NO. & PERCENT (\%) \\
\hline 1 & Strongly agree & 22 & 22 \\
\hline 2 & Agree & 47 & 47 \\
\hline 3 & Disagree & 29 & 02 \\
\hline 4 & Strongly disagree & 02 & 100 \\
\hline Total & & 100 & \\
\hline
\end{tabular}

$$
\chi^{2}=41.52 \quad \mathrm{df}=3, \quad \chi^{2}(.05)=7.81
$$

On asking to the respondents that HR practices are steady with the organization's mission, 22 $\%$ and $47 \%$ of them were strongly agree and agree in that order and only $29 \%$ were disagree and $02 \%$ were strongly disagree with the statement. Also chi square value depicts that the opinion of respondents was significantly different.

9. 2. 2. HEG is having sufficient current employees?

\begin{tabular}{|c|c|c|c|}
\hline S.NO. & OPINION & NO. & PERCENT (\%) \\
\hline 1 & Strongly agree & 14 & 14 \\
\hline 2 & Agree & 31 & 31 \\
\hline 3 & Disagree & 39 & 39 \\
\hline 4 & Strongly disagree & 16 & 16 \\
\hline Total & & 100 & 100 \\
\hline
\end{tabular}

$$
\chi^{2}=17.36 \quad \mathrm{df}=3, \quad \chi^{2}(.05)=7.81
$$

When it was asked to the employees HEG is having sufficient employees, then only $14 \%$ were strongly agree and $39 \%$ were agree While the majority of $39 \%$ and $16 \%$ were disagree and strongly disagree respectively. The chi square value completely shows that the opinion of respondents was significantly different on this fact.

9. 2. 3. Current employees are overloaded in HEG?

\begin{tabular}{|c|c|c|c|}
\hline S.NO. & OPINION & NO. & PERCENT (\%) \\
\hline 1 & Strongly agree & 13 & 13 \\
\hline 2 & Agree & 22 & 22 \\
\hline 3 & Disagree & 41 & 41 \\
\hline 4 & Strongly disagree & 24 & 24 \\
\hline Total & & 100 & 100 \\
\hline
\end{tabular}

$$
\chi^{2}=16.4 \quad \mathrm{~d} \mathrm{f}=3, \quad \chi^{2}(.05)=7.81
$$


On asking to the respondents that Current employees are overloaded in HEG, only $13 \%$ and $22 \%$ of them were strongly agree and agree in that order and mass of $41 \%$ were disagree and $24 \%$ were strongly disagree with the statement. Also chi square value depicts that the opinion of respondents was significantly different.

9. 2. 4. Work uniformly distributed among the employees because of existing HR Planning Process?

\begin{tabular}{|c|c|c|c|}
\hline S.NO. & OPINION & NO. & PERCENT (\%) \\
\hline 1 & Strongly agree & 09 & 09 \\
\hline 2 & Agree & 21 & 21 \\
\hline 3 & Disagree & 44 & 44 \\
\hline 4 & Strongly disagree & 26 & 26 \\
\hline Total & & 100 & 100 \\
\hline
\end{tabular}

$$
\chi^{2}=25.36 \quad \mathrm{df}=3, \quad \chi^{2}(.05)=7.81
$$

When it was asked to the employees that Work is uniformly distributed among the employees, then only $09 \%$ were strongly agree and $21 \%$ were agree While the majority of 44 $\%$ and $26 \%$ were disagree and strongly disagree respectively. The chi square value completely shows that the opinion of respondents was significantly different on this fact.

9. 2. 5. Rate how well HR finds good candidates from non traditional sources when necessary?

\begin{tabular}{|c|c|c|c|}
\hline S.NO. & OPINION & NO. & PERCENT (\%) \\
\hline 1 & Poor & 23 & 23 \\
\hline 2 & Adequate & 47 & 47 \\
\hline 3 & Very good & 21 & 21 \\
\hline 4 & Excellent & 09 & 09 \\
\hline Total & $\chi^{2}=30.4 \quad \mathrm{df}=3, \quad \chi^{2}(.05)=7.81$ \\
\hline
\end{tabular}

On asking respondents to rate how well HR finds good candidates from non traditional sources, only $23 \%$ said poor and $47 \%$ of them said adequate and $21 \%$ said very good while $09 \%$ said excellent. Also chi square value depicts that the opinion of respondents was significantly different. 
9. 2. 6. HEG has comprehensive job-descriptions for all the positions?

\begin{tabular}{|c|c|c|c|}
\hline S.NO. & OPINION & NO. & PERCENT (\%) \\
\hline 1 & Strongly agree & 29 & 29 \\
\hline 2 & Agree & 37 & 20 \\
\hline 3 & Disagree & 20 & 14 \\
\hline 4 & Strongly disagree & 14 & 100 \\
\hline Total & & 100 & \\
\hline
\end{tabular}

$$
\chi^{2}=12.24 \quad \mathrm{df}=3, \quad \chi^{2}(.05)=7.81
$$

When it was asked to the employees that HEG has comprehensive job-descriptions, then $29 \%$ were strongly agree and $37 \%$ were agree While only $20 \%$ and $14 \%$ were disagree and strongly disagree respectively. The chi square value completely shows that the opinion of respondents was significantly different on this fact.

9. 2. 7. HR Planning \& Audit in the organization helps to analyze effective utilization of human resources?

\begin{tabular}{|c|c|c|c|}
\hline S.NO. & OPINION & NO. & PERCENT (\%) \\
\hline 1 & Strongly agree & 15 & 15 \\
\hline 2 & Agree & 48 & 48 \\
\hline 3 & Disagree & 25 & 25 \\
\hline 4 & Strongly disagree & 12 & 12 \\
\hline Total & & 100 & 100 \\
\hline
\end{tabular}

$$
\chi^{2}=31.96 \quad \mathrm{df}=3, \quad \chi^{2}(.05)=7.81
$$

On asking to the respondents that HR Planning \& Audit helps to analyze effective utilization of human resources, $15 \%$ and $48 \%$ of them were strongly agree and agree in that order and $25 \%$ were disagree and $12 \%$ were strongly disagree with the statement. Also chi square value depicts that the opinion of respondents was significantly different.

9. 2. 8. Rate the performance of HR department in HR Audit \& Planning Process?

\begin{tabular}{|c|c|c|c|}
\hline S.NO. & OPINION & NO. & PERCENT (\%) \\
\hline 1 & Poor & 16 & 16 \\
\hline 2 & Adequate & 52 & 52 \\
\hline 3 & Very good & 19 & 19 \\
\hline 4 & Excellent & 13 & 13 \\
\hline Total & & 100 & 100 \\
\hline
\end{tabular}

$$
\chi^{2}=39.6 \quad \mathrm{df}=3, \quad \chi^{2}(.05)=7.81
$$

On asking respondents to rate performance of HR department in HR Audit \& Planning, only $16 \%$ said poor and $52 \%$ of them said adequate and $19 \%$ said very good while $13 \%$ said excellent. Also chi square value depicts that the opinion of respondents was significantly different. 


\section{FINDINGS}

- Overall the employees are quite satisfied with HR practices and view the HEG as a good place to work.

- Most of the employees of HEG belongs to different age groups and are spending dissimilar service period with the organization.

- The management of HEG, Bhopal has defined the HR planning process and system within the organization. But some officials were not sure about it.

- HR planning \& audit is a regular process in HEG which is conducted by the human resources department after a regular or defined time span.

- Most of the officials were having a different view regarding the transparency in the process of HR Planning.

- In some cases it is found that employers are not making sufficient investment in auditing the implementation of policies.

- Somewhere employers do not adequately and transparently communicate recruitment process.

- Manpower in such areas where there are high levels of demand is partially provided.

- HR audit helps in increasing quality and productivity of the work.

- It is found that most of the employees agree that they are physically stressed in their job. And some of the Employees strongly agree that they are mentally pressurized in their job.

- Majority of the employees agree that their superiors are more helpful and cooperative which may be one of the reasons for good HR planning.

- It is found that employees are more committed towards their job to get higher reward and appreciation. This attitude towards their jobs is a sign of good job description.

- Most of the employees agree that work allotment is somewhat partial.

- Employees have mutual cooperation and share their experiences to help the other employee that is a symbol of good HR planning.

- Most of the employees especially ground level employees are not happy with physical working conditions.

- Salary and Leave are two most vital factors that motivate employees.

- Most of the officials were in the favor that they consider all the factors that facilitate the audit process.

- Most of the officials were in the favor that they maintain the record of the employees.

- Job Description is clearly defined to the employees, so that they can perform their job without any hurdle.

- Some employees said that promotions are not strictly based on performance, somewhere seniority is considered for it.

- More than $60 \%$ employees are satisfied with the performance of HR department at HEG and remaining is waiting for the change in some policies for effective HR planning and audit.

\section{CONCLUSION}

Establishing a HR Planning framework and audit practices is a major achievement, that enables an organization to ensure how best to use its human resources to achieve outputs and outcomes. Employee plays crucial role in the success of business organization, it is important that organization should put consideration and careful planning into human resource practices. 
It is imperative that your Human resource practices should correspond with your business plans. Human resource planning is an ongoing process. Organization must continually monitor and forecast personnel needs and concerns. Human resource planning is something that you can learn and improve on through experience and effort. Similarly a Human Resources Audit is a comprehensive method (or means) to review current human resources policies, procedures, documentation and systems to identify needs for improvement and enhancement of the HR function as well as to ensure compliance with ever-changing rules and regulations. An Audit involves systematically reviewing all aspects of human resources. HR audit helps to link the long term purpose, goals and objectives of the HR function/HR plans. It also examines what people are presently doing in their jobs in the organization. It examines and analyze what kinds of people are doing the work at present and the present strengths and weaknesses of the HR policies. Finally it compares present and future jobs/people/HR practices.

\section{SUGGESTIONS}

- Changing culture requires leaders to understand the learning process dynamics and how the learning and unlearning of assumptions and beliefs can be manipulated to modify human needs and behavior.

- Effective HR audit requires equal standards against which procedures and implementation of policies are assessed. In the absence of equal standards, policies are assessed with subjectivity, which may destroy the process of audit.

- One training program should not be designed to serve a numerous of purposes because it may be unclear and difficult $\&$ results into failure. The solution is to separate training and assessment program should be designed for development of employees.

- HR planning should be job-related. Job description should be given to the employees. Bring them into the line of organization's goals with the job objectives so that every employee's work lead to the organizational goal.

- Since the goal of HR planning system is to achieve the organizational goal. Hence there is immense need to coach the employee before and after appointment regularly. Provide the resources required by them to get to the management's expectations.

- Deliver training and development for new and experienced employees that enhances critical competencies and behaviors.

- Create career development systems that identify, prepare, and promote employees whose experience and skills match the demands of higher-level positions.

- Design the system which is free from biasness and favoritism because it discourages the employee when it comes to appointment of employees in a long run case.

- Review the systems that support the on-going relationship with the employee. This includes looking at the performance management system, assessing the state of your compensation structures, training and development, plus looking how you handle employee grievances or complaints.

- Company should assess how well do you inform and educate your employees on your policies, procedures, and practices.

- Improper information should not be retained in primary personnel files.

- HEG should review its existing human resource policies to ensure completeness and relevance to the department's current context; ensure widespread communication and understanding of human resource policies; regularly monitor compliance to human resource policies; and update human resources policies on an ongoing basis. 
- When management establishes targets in their human resource plan, management should ensure that strategies are established to achieve those targets.

- Suitable policies and procedures to support the development and management of human resources are established, maintained, and communicated.

- HEG should consider developing a multi-year integrated business and human resource plan for the department that is adjusted annually to reflect the priorities of the current year.

- HEG must consider all the available options for strategically promoting job openings and encouraging suitable candidates to apply.

- Determine the gap between where your organization wants to be in the future and where you are now. The gap analysis includes identifying the number of staff and the skills and abilities required in the future in comparison to the current situation.

- HR Planning and audit objectives can be achieved successfully when there is a link or alignment between organizational and unit objectives so to avoid the conflict between team and organization's objectives.

\section{References}

[1] About HEG, Bhopal, Available from www.hegltd.com/

[2] Dave Ulrich, Human Resource Management 36(3) (1997) 303-320.

[3] Dr. Shikha N. Khera, Ms. Karishma Gulati, Journal of Business and Management 3(6) (2012) 06-13.

[4] Ghazala Ishrat, Javed Habib, Journal of Business and Management 6(2) (2012) 01-08.

[5] Gupta C. B. (2008). "Human resource management", Sultan chand and sons educational publishers, pp. 5.3-5.26 \& 34.3-34.14.

[6] Kothari C. R. (2004). "Research methodology - methods and techniques", new age international publishers, pp. 233-238.

[7] Linda O'Brien-Pallas, Stephen Birch, Andrea Baumann, Gail Tomblin Murphy, Human Resources for Health Development Journal 5(1-3) (2001) 01-16.

[8] Mark S. Van Clieaf (1992). "Strategy and Structure Follow People: Improving Organizational Performance Through Effective Executive Search", Human Resource Planning, Volume 15, No. 1.

[9] Pravin Durai (2010). Human resource Management (Book), Pearson education Publications.

[10] Sanjeev K. Bordoloi, Hirofumi Matsuo, European Journal of Operational Research 130 (2001) 169-189.

[11] Rajesh K. Yadav, Nishant Dabhade, International Letters of Social and Humanistic Sciences 8 (2013) 77-85. 